\title{
The Effect of Parenting Style, Self-Efficacy, and Self Regulated Learning on Adolescents' Academic Achievement
}

\author{
Julia Theresya*)1 $^{*}$, Melly Latifah ${ }^{2}$, Neti Hernawati ${ }^{3}$ \\ ${ }^{1}$ Pusat Studi Bencana-Adaptasi Perubahan Iklim (PSB-API), Universitas Pertahanan \\ ${ }^{2,3}$ Department of Family and Consumer Sciences, Faculty of Human Ecology, Bogor \\ Agricultural University, Bogor 16680, Indonesia \\ *Corresponding author: jtheresya@gmail.com
}

\begin{abstract}
Academic achievement as one of learning outcome indicator in adolescents influenced by theself and family environment factors. This study was aimed to analyze the effect of child characteristics, family characteristics, parenting style perceived byadolescents, self-efficacy and self regulated learning on adolescents academic achievement. The study used self report method which involved 91 eighth grade students from two junior high schools in Bogor. Data analysis included descriptive analysis and inference analysis (correlation test and linier regression test). Result showed that majority of samples perceived their parent as authoritative $(86.8 \%)$ followed by authoritarian $(11.0 \%)$ and permissive $(2.2 \%)$. The result also showed that majority of samples had medium level in self-efficacy and self regulated learning. More than a half of samples had under average level in academic achievement. Correlation resultsshowedthat there were significant and positiverelationshipbetweenauthoritarianparentingstylewithbirth order, family size as well as gender. Self regulated learning were significantly andpositively relatedwith authoritativeparentingstyle $(r=0.257, \mathrm{p}$-value $<0.05)$ andself-efficacy $(r=0.330, \mathrm{p}$ value $<0.01)$. Meanwhile, regressionresultsshoweda positive effect ofacademicachievement on father's education $(\beta=0.315, \quad p$-value $=0.006)$ and authoritativeparenting styles $(\beta=0.259, p$-value $=0.014)$, as well asnegatively on gender $(\beta=-0.267, p$-value $=0.014)$ and permissiveparentingstyle $(\beta=-0.203, p$ value $=0.039)$.
\end{abstract}

Keywords: parenting style, self-efficacy, self regulated learning, academic achievement

Abstrak. Prestasi akademik sebagai salah satu indikator pencapaian hasil belajar remaja dipengaruhi oleh faktor dari dalam diri dan lingkungan keluarga. Penelitian ini bertujuan menganalisis pengaruh karakteristik remaja, karakteristik keluarga, gaya pengasuhan orang tua menurut persepsi remaja, self-efficacy, dan self regulated learning terhadap prestasi akademik remaja. Penelitian menggunakan teknik self report yang melibatkan 91 siswa kelas VIII dari dua sekolah menengah pertama di Bogor. Hasil korelasi menunjukkan bahwa terdapat hubungan yang positif 
signifikan antara gaya pengasuhan otoriter dengan jenis kelamin, urutan kelahiran, dan besar keluarga. Self regulated learning berhubungan positif signifikan dengan gaya pengasuhan otoritatif $(\mathrm{r}=0.257, p$-value $<0.05)$ dan self-efficacy $(\mathrm{r}=0.330, p$ value $<0.01)$. Sementara itu, pendidikan ayah $(\beta=0.315, p$-value $=0.006)$ dan gaya pengasuhan otoritatif $(\beta=0.259, p$-value $=0.014)$ berpengaruh positif terhadap prestasi akademik, serta jenis kelamin $(\beta=-0.267$, $p$-value $=0.014)$ dan gaya pengasuhan permisif $(\beta=-0.203$, $p$-value $=0.039)$ berpengaruh negatif.

Kata kunci: gaya pengasuhan, self-efficacy, self regulated learning, prestasi akademik

\section{Introduction}

Adolescence is the phase of optimization of cognitive aspects related to intellectual ability such as the ability to understand, digest, and solve problems in the learning process. Success or failure of adolescents in this phase of cognitive one can be known from the achievement of learning outcomes in schools in the form of academic achievement. Academic achievement shows how far the results achieved by students during the learning process within a certain time and usually expressed in the form of assessment. In social learning theory, one will learn by observing the behavior of others around it called the model (Hastuti 2009). Both parents, schools and other social environments around adolescents will influence and regulate learning behaviors and academic achievement.

Pintrich and De Groot (1990) also reveal factors that affect academic achievement such as differences in child characteristics in terms of motivation, selfregulation, social and cognitive conditions of children. Some internal factors such as cognitive achievement, academic behavior and logical competence will interact and arise as a result of adolescent academic process. Basically the cognitive system also affects how high the level of awareness and understanding in determining learning behavior and academic goals. Awareness and understanding is a part of self or self that will be the motive of behavior and different between individuals. This is why teenagers have different self-efficacy as well.

Data from TIMSS (Trends in International Mathematics and Science Study) in 2011 shows the achievement of Mathematics and Science of Indonesian students is still far behind compared to other participant countries. Based on the eighth grade Mathematics Achievement data, Indonesian students scored 386 or far below TIMSS scale centerpoint (500) and ranked 38th out of 42 participating countries. Meanwhile, in Science Achievement Indonesian students scored 406 and ranked 40th out of 42 participating countries (IES 2011).

This shows that the ability of teenagers has not been developed optimally in achievement of academic achievement. The problems that arise are many teenagers who have good academic potential or have above average intelligence but can not achieve high achievement in school. It may be caused by other factors in adolescents 
that affect academic achievement such as self-efficacy and self regulated learning. Self-efficacy is a person's belief that he or she is capable of mastering the situation and producing positive outcomes (Santrock 2002). This belief can lead to the strength and usefulness of adolescent thinking so as to be able to organize everything a teenager wants to achieve.

Adolescent knowledge and academic ability must also be balanced by good self-efficacy, since self-efficacy can help adolescents to face difficult tasks to determine learning objectives and strategies. Through the ability of the organization and strategy, then self-efficacy can affect the self-regulated learning of adolescents. Schunk and Meece (2005) revealed that self-efficacy, either directly or indirectly, affects the academic achievement obtained anak.Pada research Ho (2005) found that self-efficacy indicators have the strongest relationship affecting self regulated learning.

Bandura et al. (2003) also revealed that in the self-efficacy of children will directly affect the ability of self-regulation, cognition, effectiveness, interest and decision making, especially in the academic process. Differences in self-regulated learning in adolescent learning are determined by internal factors, especially biological and psychological developments. rtThere are teenagers who are able to use self regulated learning strategy well, but there are also teenagers who have not been able to use this strategy to optimize the learning outcomes. Self regulated learning is basically not only related to logical and mental processes, but also the emotional and motivational conditions of learning (Salmeron-Perez et al., 2010). Self-efficacy and self-regulated learning are thought to have evolved from the results of the youth learning environment and parental involvement, in this case the applied parenting style.

According to Vygotsky's social interaction theory referred to in Hastuti (2009), social interaction between the child's mind-set and caregiver is an important key to the child's cognitive development. Every parent would want their children to be clever, intelligent and morally human. However, many parents are unaware that a way of educating and caring is too restrictive or too loose to make teenagers lose confidence or reduce the motivation of teenagers to excel. Some studies have found that in adolescents of interpersonal competence and changes in development including social academic performance are also adapted from the family environment, especially parenting behavior (Santrock 2002).

This also revealed by Grolnick and Ryan (1989), one that affects adolescence competence in school is family environment. The family environment shows some relation between parents and child that affect each other, especially parenting behavior dimention. In this case, family environment also provide learning pattern and facility in the form of parenting style. Some of this parenting syles are authoritarian, permissive, and authoritative (Baumrind, 1967). The good parenting style allegedly will create good emotional situation and enhancing self confidence of child in a learning process, so that the academic achievement is also enhance. The study aims to analyze the influence of parenting style, self-efficacy, and self regulated learning toward academic achievement in adolescents 


\section{Methods}

\section{Design, Location, and Time}

This study used cross sectional study design. The research was conducted in two junior high schools in Bogor. The determination of the school used as the research location is done purposively with consideration based on the willingness of the school as the respondent and has the characteristics of the heterogeneous students. The study was conducted for three months from March to May 2013.

\section{Sampling Technique}

The population of the study were VIII students in two junior high schools, from SMP Negeri 1 Dramaga with 394 people and SMP Negeri 5 Bogor with 372 people. The total study population amounted to 766 people. Determination of the sample is based on the consideration that the students of grade VIII have had experience in junior high school longer than class VII, but not preoccupied with the preparation of National Final Exam like class IX. Based on the consideration of the minimum sample amount of 89 samples and $20 \%$ of reserves, the total sample number for this study is 108 randomly selected samples. However, sample data that met the criteria and processed to the end of the study amounted to 91 samples.

\section{Instruments}

Parenting styles were measured using a questionnaire about parenting style perceptions that were divided into three types, namely authoritarian, permissive, and authoritative. These three parenting styles consist of dimensions of demandingness (control) and responsiveness (warmth). This variable consists of 30 questions (9 questions of authoritarian parenting style, 12 questions of permissive parenting style, and 9 questions of authoritative parenting style) with Likert scale. The reliability of the parenting questionnaire is 0.843. Self-efficacy was measured using a questionnaire that refers to a self-efficacy questionnaire compiled by Hambawany, regarding adolescent self-efficacy. This self-efficacy variable consists of 24 questions with Likert scale. The reliability of the self-efficacy questionnaire is 0.790 . Self regulated learning is measured using a scale-shaped questionnaire that refers to the Motivated Strategies for Learning Questionnaire (MSLQ) tool developed by Pintrich on motivational orientation and the use of student learning strategies related to learning behavior and student achievement. This instrument consists of two main dimensions of motivation and learning strategies. Self regulated learning variable consists of 81 questions answered by using Likert scale. The reliability of the self regulated learning questionnaire is 0.892 .

\section{Data Collection}

The data collected includes primary data and secondary data. Primary data was collected through self report technique with questionnaire tool filled by example after got explanation and guide from researcher. Primary data include adolescent 
characteristics (sex, age, birth order), family characteristics (parent's education, income per capita, family size), parenting style, self-efficacy, and self regulated learning. Secondary data consists of academic achievement obtained from the school. Academic achievement is seen from the average value of sample report cards in grade 7 semester 2 and grade 8 semester 1 . The average value of sample report cards obtained from the average total value of 10 subjects, namely PKN, IPA, IPS, Religion, Mathematics, Bahasa, English, Physical Education, Cultural \& Art, and IT.

\section{Data Processing and Analyzing}

Data obtained through processing and analyzed descriptively and inferensia. Data processing includes entrying, cleaning, editing, scoring, coding, and analyzing. Processing and data analysis is done by using Microsoft Excel program and SPSS for Windows. The frequency analysis is done descriptively. Statistical analysis of inferences used, among others: (1) Pearson correlation test used to see the relationship between adolescent characteristics, family characteristics, parenting style, self-efficacy, self regulated learning, and academic achievement; and (2) multiple linear regression test used to find out the influence of adolescent characteristics, family characteristics, parenting style, self-efficacy, self regulated learning, and academic achievement.

\section{Findings}

\section{Adolescence Characteristics}

Gender. The largest percentage of female sex samples is 53.8 percent and the remaining men are 46.2 percent. Age. Adolescence is classified as early adolescence ie age 12 to 15 years. More than half of the samples (58.2\%) were in the 14-14.11 years age range. The average age of the sample is $13.9 \pm 0.5$ years.

Birth order. Nearly half of the examples $(41.8 \%)$ belong to the category of the firstborn in the family. The mean birth order example is $2.0 \pm 1.3$.

\section{Family Characteristics}

Family Number. Large families are divided into three categories, namely small families, medium families and large families. More than half of the samples $(50.5 \%)$ belong to a small family ( $\leq 4$ people). The average large sample family is $5 \pm 1.1$ people. Education of Father and Mother. The greatest percentage of fathers and mothers has gone to senior high school education of 47.3 percent and 53.8 percent. The average father of the sample has been educated for $12.1 \pm 4.2$ years, while the average mother of the sample has been educated for $11.6 \pm 3.5$ years. Family Income Per Capita. Per capita income indicates that more than one-fourth of sample families (28.6\%) have revenues above Rp1 286029 with an average of Rp1 $158082 \pm 1151$ 863. 


\section{Parenting Style}

Parenting is an act by parents to be responsible, contributing as a member of the community, including what it does when confronting the child's emotions such as crying, aggressive, lying or showing inadequate competence in education. According Baumrind (1967), parenting style is divided into 3, namely authoritarian, permissive, and authoritative. Most examples perceive authoritative parenting styles of $86.8 \%$. A total of $11 \%$ of examples perceive authoritarian parenting styles. A total of $2.2 \%$ of examples perceive permissive parenting styles.

Per item question analysis shows more than half of the examples reply 'never' to authoritarian parenting items such as parents forcing additional lessons, giving no explanatory penalties, and determining with whom to associate examples. In the permissive parenting questioning items, more than half of the examples reply 'never' to statements like parents never get angry even though I argue, free association without any restrictions, and do not apply any rules. Meanwhile, in the authoritative parenting style the largest percentage of examples are those that answer 'often' across the question items.

\section{Self-Efficacy}

Self-efficacy is a situation where one is convinced and believes that he or she can control the outcome of the effort done. Over three-fourths of the samples (78\%) have self-efficacy falling into the moderate category, as many as $15.4 \%$ of examples belong to low self-efficacy, and the rest $(6.6 \%)$ in the high category. The average percentage of sample scores is $68.4 \% \pm 7.8$. In per item question analysis, the examples tend to answer 'agree' to positive statements as I am confident of achieving goals after graduation, I am sure I can prepare the exam well despite many obstacles. Examples tend to answer 'disagree' for negative questions like I feel not confident in competing with a smarter person, I feel unable to deal with difficult situations. However, for negative statements like me often anxiously awaiting the results of the exam, more than half of the examples answered 'agree'.

\section{Self Regulated Learning}

Self regulated learning is the foundation of a lifelong learning process that teaches learners to control their thoughts, attitudes and actions in a planned and orderly way to achieve learning goals (Zimmerman 1989). Measurements of self regulated learning consists of two main measurements of learning motivation and learning strategies. The result of the six dimensions of learning motivation measurement, it is known that the largest percentage of examples are in moderate category in almost all dimensions, except the extrinsic goal orientation (EGO) dimension. As for the low category, task anxiety (TA) dimension has the largest percentage of sample split or nearly half sample (41.8\%). While in the high category, the extrinsic goal orientation (EGO) dimension has the largest sample split or more than half the sample $(58.2 \%)$.

The results of the 9-dimensional distribution of learning strategy measurements show that the largest percentage of samples are in moderate categories across 
dimensions. In the low category, the time / study environmental management (SEM) dimension has the largest percentage of sample distributions or nearly half of samples (44\%). While in the high category, the dimension of effort regulation (ER) and help seeking (HS) has the largest sample distribution (14.3\%).

The result of measurement of learning motivation, learning strategy, and total self regulated learning do not show significant difference with measurement per dimension. Almost all examples are in the moderate category of learning motivation $(84.6 \%)$ with an average percentage score of $70 \% \pm 6.9$. Over three-fourths of the samples $(75.8 \%)$ were also categorized as learning strategies with an average percentage score of $65 \% \pm 7.2$. The total self-regulated learning of $87.9 \%$ of the sample is also in the medium category and only $9.9 \%$ of the samples are highly categorized, with the average percentage score of $67 \% \pm 6.1$.

Table 1. The sample distribution based on self regulated learning

\begin{tabular}{lcccccc}
\hline \multirow{2}{*}{ Categories } & \multicolumn{2}{c}{ Learning motivation } & \multicolumn{2}{c}{ Learning strategy } & \multicolumn{2}{c}{ SRL } \\
\cline { 2 - 7 } & $\mathrm{n}$ & $\%$ & $\mathrm{~N}$ & $\%$ & $\mathrm{n}$ & $\%$ \\
\hline Low $(<60 \%)$ & 8 & 8.8 & 19 & 20.9 & 9 & 9.9 \\
Medium $(60 \%-80 \%)$ & 77 & 84.6 & 69 & 75.8 & 80 & 87.9 \\
High $(>80 \%)$ & 6 & 6.6 & 3 & 3.3 & 2 & 2.2 \\
\hline Total & 91 & 100.0 & 91 & 100.0 & 91 & 100.0 \\
Min - max & $56.0-88.0$ & $44.0-83.0$ & $51.0-81.0$ \\
Mean \pm std. & $70.0 \pm 6.9$ & $65.0 \pm 7.2$ & $67.0 \pm 6.1$ \\
\hline
\end{tabular}

\section{Academic Achievement}

Everyone doing the learning process will experience a change. The level of success of a person in learning the subject matter after experiencing the learning process is indicated by the achievement of academic achievement. More than half the sample $(58.2 \%)$ is in the category below average, while as many as $41.8 \%$ of the sample is in the category above average. The average academic achievement of the sample is $79.1 \pm 3.7$.

\section{Correlations between Adolescence Characteristics and Family Characteristics with Parenting Style and Self-Efficacy}

Parenting styles applied by parents tend to be related to the characteristics of adolescents, the state and the socio-economic conditions of the family. Young men tend to perceive an authoritarian parenting style $(\mathrm{r}=0.317, \mathrm{p}$-value $<0.01)$ (Table 2).

The birth order example is known to have a significant positive relationship with authoritarian parenting style $(\mathrm{r}=0.282$, $\mathrm{p}$-value $<0.01)$, as well as a significantly negative association with the authoritative parenting parenting style $(r=-0.272$, $p$ value <0.01) (Table 1). This means that the younger the order of birth of the example, the parenting style is more authoritarian or not authoritative. In this study, most younger children have siblings who have entered adulthood, therefore parents tend to provide tighter care for younger children as they still need more attention. 
In the family characteristics, there is a significant positive relationship between large family with authoritarian parenting style $(\mathrm{r}=0.337$, $\mathrm{p}$-value $<0.01)$ (Table 1$)$. This means that the more number of members in the sample family, the parenting style is more authoritarian. $81.8 \%$ of examples that perceive authoritarian parenting styles come from middle and extended families.

Table 2 Coefficient of correlation between adolescent characteristics, family characteristics, parenting styles, and self efficacy

\begin{tabular}{lrrrr}
\hline \multirow{2}{*}{$\begin{array}{l}\text { Correlation between } \\
\text { variables }\end{array}$} & \multicolumn{3}{c}{ Parenting styles } & \multirow{2}{*}{ Self-efficacy } \\
\cline { 2 - 4 } Adolescent characteristics & Authoritarian & Permissive & Authoritative & \\
\hline Sex & $0.317^{* *}$ & -0.089 & -0.062 & 0.201 \\
Age & 0.021 & 0.127 & -0.018 & -0.068 \\
Birth order & $0.282^{* *}$ & -0.094 & $-0.272^{* *}$ & 0.145 \\
\hline Family characteristics & & & & \\
\hline Family number & $0.337^{* *}$ & -0.045 & -0.205 & 0.058 \\
Father education & -0.086 & 0.120 & 0.114 & -0.023 \\
Mother education & -0.067 & -0.028 & 0.152 & -0.113 \\
Per Capita Family Income & -0.092 & 0.132 & -0.033 & 0.085 \\
\hline
\end{tabular}

Notes: *significant atp-value $<0.05 ; * *$ significant at $p$-value $<0.01$

\section{Correlations between Parenting Style, Self-Efficacy andSelf Regulated Learning}

Parental involvement is also an important factor in improving self-efficacy and self-regulated learning among adolescents. In Table 3, the Pearson correlation test between self-efficacy and self-efficacy indicates that there is no significant relationship between self-efficacy and the three parenting styles. There is a significant positive relationship between authoritative parenting style and self regulated learning $(\mathrm{r}=0.257$, $\mathrm{p}$-value $<0.05)$. The other results show that self-efficacy is positively significant with self regulated learning $(r=0.330$, $\mathrm{p}$-value $<0.01)$. This means that the higher the self-efficacy example, the higher the self-regulated learning.

Table 3 Coefficient of correlation between parenting style,self-efficacyandself regulated learning

\begin{tabular}{lrr}
\hline Correlation between variables & Self-efficacy & \multicolumn{2}{c}{ Self regulated learning } \\
\hline Authoritarian & -0.034 & 0.023 \\
Permissive & -0.096 & -0.142 \\
Authoritative & 0.182 & $0.257^{*}$ \\
Self-efficacy & 1.000 & $0.330^{* *}$ \\
\hline
\end{tabular}

Notes: *significant atp-value $<0.05 ; * *$ significant at $p$-value $<0.01$

\section{Correlations between Self Regulated Learning with Academic Achievement}

Based on the test of relationship between self regulated learning and academic achievement of the sample, no significant relationship was found between the two. 
The result of relationship test shows that the correlation coefficient between self regulated learning is 0.018 with $p$-value $>0.05$. This is related to the result of learning motivation measurement, indicating that the sample is still low in the dimension of anxiety test. Examples tend to think about things related to failure when the exam. These anxieties and fears often interfere with the instance when they are facing exam, so the result was less than the maximum.

In the measurement of learning strategies, the sample is still low in its ability to regulate the learning environment (time/study environmental management). Examples feel the difficulty of sharing focus and study time with other activities, and difficult to create a conducive atmosphere for learning activities. These problems can also hinder the examples to achieve good performance in school.

\section{Influence of Adolescent Characteristics, Family Characteristics, Parenting Style, Self-Efficacy, and Self Regulated Learning on Academic Achievement}

The results of multiple linear regression tests on the model (Table 3 ) shows that the value of adjusted coefficient of determination (Adjusted R Square) of 0.288 and 71.2 percent explained by other variables outside the variables studied. The gender was found to have a significant negative effect on the academic achievement $(\beta=$ 0.267, p-value $=0.014$ ), meaning that the male adolescent was significantly correlated with the decrease of academic achievement of 0.267 . Father's education has a significant positive effect on academic achievement $(\beta=0.315$, $\mathrm{p}$-value $=$ 0.006), meaning that every 1 year increase of father's education will increase the academic achievement of samples of 0.315 .

Permissive parenting style has a significant negative effect on academic achievement $(\beta=-0.203$, $\mathrm{p}$-value $=0.039)$, it means that every increase of 1 perception score of permissive parenting style will decrease the academic achievement of 0.039. On the other hand a significant positive influence was found in authoritative parenting style on academic achievement $(\beta=0.259$, $p$-value $=0.014)$, meaning that any increase of 1 score of perceptions of authoritative parenting style will increase academic achievement of 0.259 .

Table 3 Regression coefficient of adolescent characteristics, family characteristic of family, nurture style, self-efficacy and self regulated learning toward academic achievement

\begin{tabular}{lrr}
\hline \multirow{2}{*}{ Variables } & Academic achievement & \\
\cline { 2 - 3 } & $\mathrm{B}$ & Sig. \\
\hline Constanta & - & 0.000 \\
Sex & -0.267 & $0.014^{*}$ \\
Age & -0.084 & 0.386 \\
Birth order & 0.224 & 0.121 \\
Family order & -0.224 & 0.093 \\
Father education & 0.315 & $0.006^{* *}$ \\
Mother education & 0.098 & 0.402 \\
Family income & 0.060 & 0.587
\end{tabular}




\begin{tabular}{lrr}
\hline \multirow{2}{*}{ Variables } & Academic achievement & \\
\cline { 2 - 3 } & $\mathrm{B}$ & Sig. \\
\hline Authoritarian & 0.126 & 0.251 \\
Permissive & -0.203 & $0.039^{*}$ \\
Authoritative & 0.259 & $0.014^{*}$ \\
Self-efficacy & 0.184 & 0.078 \\
\hline Self regulated learning & -0.134 & 0.221 \\
$\mathrm{~N}$ & & 91 \\
$\mathrm{Df}$ & & 1 \\
$\mathrm{R}^{2}$ & & 0.383 \\
$\mathrm{R}^{2}$ adjusted & & 0.288 \\
$\mathrm{~F}$ & & 4.034 \\
\hline
\end{tabular}

Notes: *significant atp-value $<0.05 ; * *$ significant at $p$-value $<0.01$

\section{Discussion}

The parenting style applied by parents tends to be related to the characteristics of adolescents, the state and the socio-economic conditions of the family. Characteristics of children such as gender into consideration of parents in interacting with their children. In research, adolescent boys tend to perceive authoritarian parenting style. These results are consistent with Dornbusch et al. (1987) who found that there were significant differences between adolescent boys and girls in terms of authoritarian parenting style. Young women are less likely to accept authoritarian parenting styles than boys. Unlike the results of research Stephens (2009) which suggests that parents, especially fathers more overprotected and authoritarian behavior in adolescent girls compared with adolescent boys. Basically the nurture style does not distinguish the sex of the child, both men and women need a nurturing style that leads to authoritative parenting style (Hastuti 2009). However, feminine and masculine impression that arise in children, tends to perceive that girls need a softer interaction, while men require stronger and stronger interactions.

In addition to teen sex, birth order in general can also affect parenting style. The eldest child in the family tends to accept authoritarian parenting style, because the knowledge and experience of parenting in parenting tend to be minimal, so excessive in protecting the child. However, the results of the study also found that the youngest the sequence of children, the parenting style more authoritarian $(\beta=0.282$, p-value <0.01). This result is in line with the results of Rahmaisya's (2011) study which found that the youngest the order of the child, the parenting style is increasingly not authoritative, tend to be authoritarian or permissive. In this study, most of younger children have siblings who have entered adulthood, therefore parents tend to provide tighter parenting to the youngest because they still need more attention.

As for the characteristics of adolescents, the style of parenting is also related to condition and family environment. As many as $81.8 \%$ of examples that perceive authoritarian parenting styles come from moderate families and extended families. 
Due to the overly complex interactions in the sample family, the parent may be giving excessive firmnessas compensation in protecting his child. Hastuti (2009) also revealed that interpersonal interaction between family members will be more complex with the increasing number of family members. The results of research in line because of the density will affect the relationship and communication patterns between family members that run improperly, as well as parenting practices.

Although the characteristics of adolescents and families relate to parenting styles, adolescent self-efficacy is unrelated to both of these characteristics. Emotional motivation, social models appropriate for children, and how much parents teach children in problem solving are more effective in improving self-efficacy (Schunk \& Meece 2005). Parental involvement is also an important factor in improving adolescent self-efficacy. However, in this study the three parenting styles are not related to self-efficacy examples. Shaw (2008) reveals a similarity in the absence of a significant relationship between parenting style and academic self-efficacy. Meanwhile, different results were found in the study of Tam et al. (2012) which reveals that authoritative parenting styles are positively associated with adolescent self-efficacy. Authoritative parenting styles tend to play a vital role for teen-level self-efficacy compared to authoritarian and permissive parenting styles. Baumrind (1967) also states that children living in authoritative families will live their lives with a sense of confidence and self-control in managing their emotions and goals. parenting style is concerned with the ability of adolescents to control themselves, manage their emotions and goals.

As Baumrind stated, parenting style is concerned with the ability of adolescents to control themselves, manage their emotions and goals. In adolescence, this ability is also included to manage the academic goals or called self-regulated learning. The process of self-regulated learning is shown through adolescent behavior in academic or school life, closely related to parenting behavior (Purdie, Carrol \& Roche 2004). In this study, authoritative parenting style is associated with high selfregulated learning in the examples. These results are consistent with the results of Erden and Uredi (2008) studies which suggest that students with authoritative parents are higher in using self-cultivated, cognitive and metacognitive self-regulated strategies than students with authoritarian and permissive parents.

Authoritative nurturing styles tend to respond in the form of attitudes and behaviors that support child psychological autonomy, then can produce good selfesteem and self-regulation in children (Maccoby \& Martin 1983). This is related to the results of research showing the examples tend to have high extrinsic goal orientation compared to other dimensions in the measurement of learning motivation, as well as the high effort regulation and help seeking in the measurement dimension of learning strategy. Examples have the motivation to achieve learning goals that come from outside the self, such as the desire to show his achievements in the parents and family. Examples also have a good effort and hard work to obtain maximum learning results. In solving learning problems, examples are also reluctant to ask for 
help from their mentors, teachers, friends, and trusted people. The authoritative nurturing style does not employ rigid, responsive and responsive interactions to listen to child feelings and complaints (Baumrind 1967).

Not only developing from parenting style, self-regulated learning is also closely related to the self-efficacy of teenagers. The results showed that the higher the self-efficacy example the higher the self-regulated learning. According to Bandura (2003), self-efficacy affects adolescents in planning strategies for achieving their goals. Adolescents will set goals and set learning strategies that are believed to be implemented in accordance with their competencies or abilities. Accordingly, Zimmerman and Martinez-Pons (1990) research also states that the perception of academic self-efficacy is positively associated with the use of self-regulated learning strategies in all types of academic competence, both verbal and mathematical. Selfefficacy has four kinds of functions that determine the choice of behavior, determine how much the level of commitment, effort made, and persistence of effort, affect the mindset and emotional reactions, and determine the standard that will be done next. In terms of academic achievement, self-efficacy is an important aspect in determining self-regulation and individual mindset management strategies (Bandura in Santrock 2002).

Academic achievement is basically an outcome that one of them comes from the process of self-regulated learning. However, the results of this study do not find an association between self-regulated learning and academic achievement, not in line with the results of Pintrich and De Groot's (1990) research which states that highvalue students use more self-regulatory strategies than low-value students. This is related to the results of the measurement of learning motivation, which shows that the sample is still low in the dimension of anxiety test. Examples tend to think about things related to failure when the exam. Such anxiety and fear often disturb the example when facing the test, so the result is less than the maximum. In the measurement of learning strategies, the sample is still low in its ability to regulate the learning environment (time / study environmental management). Examples feel the difficulty of sharing focus and study time with other activities, and difficult to create a conducive atmosphere for learning activities. These problems can also hinder the example to achieve good performance in school.

In line with the theory expressed by Bandura, the formation of behaviors associated with achievement of academic achievement is also the result of interaction between personal and environmental factors. Personal factors such as self-efficacy and self-regulated learning are not the only ones that affect academic achievement and not the single most important factor. Self-efficacy that has been formed within the self can not produce good competence if the required knowledge and skills are inadequate (Schunk \& Meece 2005). Students who use self-regulated learning are also differentiated by systematic use of metacognitive, motivational and behavioral strategies, responses to the effectiveness of learning, and self-perception towards achievement. However, for students who are still lacking in their desires and academic abilities need the help of educators to be able to use the self regulated 
learning process well and achieve optimal academic achievement (Zimmerman 1990).

If adolescents' ability in self-efficacy and self regulated learning can affect academic achievement either directly or indirectly, the biological factors of adolescents may have equal contributions to achievement of academic achievement. As in the results of research showing that male examples have a significant effect on declining academic achievement. In line with the research of Long et al. (2007) that significantly boys tend to have lower academic achievement than girls. In the achievement of academic achievement, boys tend to be more focused on results (performance goal oriented), while adolescent girls tend to focus on learning process (learning goal oriented). These results differ from those of Maccoby and Jacklin referred to in Hastuti (2009) that men are more aggressive, more capable of visualspatial, achievement-oriented or achievement, while women have higher verbal and social abilities. Adolescents in their developmental stages have different needs from other stages. Different growths in male and female adolescents both physical and psychic will also affect the overall behavioral pattern, not least in the achievement of academic achievement.

In terms of environmental factors that affect academic achievement, father education and parenting style show significant influence. Higher father education has a greater contribution to high adolescent achievement. Farooq et al. (2011) revealed the results of research that highly educated fathers such as scholars and masters had more influence on high school child achievement compared to low level of father education. Highly educated parents, relatively wealthier in providing better stimulation to children, have relatively more time allocations with children, interact more often, and are better able to provide sufficient costs for curricular and extracurricular activities to their children.

That, authoritative parenting styles better influence its high academic achievement than permissive and authoritarian parenting styles. Equivalent to the results of the study, Dornbusch et al. (1987) also found a significant negative relationship between authoritarian and permissive parenting styles with adolescent academic values, whereas a significant positive relationship exists in authoritative parenting style with the academic value of adolescents, both male and female. In contrast to the results of other studies that found no significant relationship between authoritative parenting style and adolescent academic achievement and a significant positive relationship betweena permissive parenting style with adolescent academic achievement (Alfiasari, Latifah \& Wulandari 2011). Adolescents who are in permissive care are very immature in various psychosocial aspects, insecure, unemotional, and hesitant due to lack of parental guidance and direction. Conversely, the quality of interaction patterns and parenting style of authoritative parents will elicit courage, motivation and adolescent independence in the face of its future (Baumrind 1967). 


\section{Conclusion and Recommendation}

\section{Conclusion}

Based on the results of research, the researchers can determine the following conclusions:

1. Based on the characteristics of adolescents, Young men tend to perceive an authoritarian parenting style. Young men are also associated with declining academic achievement. Young men tend to focus more on extra activities outside school hours such as extracurricular.

2. Based on the characteristics of the family, the younger the birth order the parenting style the more authoritarian. The greater the number of family members, the more authoritarian parenting style. The higher the education of the father, the more increasing the academic achievement of adolescents.

3. More than half of adolescents still have below average academic achievement, although most teenagers accept an authoritative parenting style from parents and have moderate self-efficacy.

4. Overall, self-regulated learning adolescents fall into the medium category. However, adolescents tend to be low in text anxiety and time / study environmental management dimensions, meaning that teenagers are still difficult to control anxiety and create a conducive environment in their learning process. More than half of teenagers have extrinsic goal orientation, as well as on more teenage learning strategies that achieve high categories in the dimensions of effort regulation and help-seeking. Adolescents have a good effort to control themselves and seek help when faced with learning problems.

5. The more authoritative parenting style and the higher the self-efficacy, the higher the self-regulated learning of adolescents.

6. Authoritative parenting styles proved best in encouraging adolescent achievement in school compared to the other two styles. Permissive nurturing style has an effect on degrading academic achievement of adolescent, in contrast to authoritative parenting style which has an effect to improve youth academic achievement.

\section{Recommendation}

Considering the results of the study have revealed that the factors that affect academic achievement are gender, father education, permissive parenting style, and authoritative parenting style, it is suggested to:

1. Parents to reduce permissive parenting and promote more authoritative or democratic nurturing, which can increase motivation and self-confidence, especially in boys. Parents should also be a role model that is prestatif for teenagers, can help create a conducive learning atmosphere so that teenagers can be maximized in the process of achieving the achievement. 
2. Schools can act as parent partners in creating a conducive and comfortable learning environment for students. In addition, teachers and schools should also improve control and warmth with adolescent students, so that teenagers are motivated to improve academic achievement.

3. For further research, it is expected to be able to further examine the factors that influence academic achievement in addition to individual and family environment, such as peer group and school environment.

\section{References}

[IES]. Institute of Education Science. 2011. Overview TIMSS and PIRLS Achievement 2011. USA: IES.

Alfiasari, Latifah M, Wulandari A. 2011. Pengasuhan otoriter berpotensi menurunkan kecerdasan sosial, self-esteem, dan prestasi akademik remaja. Jurnal Ilmu Keluarga dan Konsumen. 4 (1), 46-56.

Bandura A, Caprara GV, Barbaranelli C, Gerbino M, Pastorelli C. 2003. Role of affective self-regulatory efficacy in diverse spheres of psychosocial functioning. Child Development. 74(3), 769-782.

Baumrind D. 1967. Child-care practices anteceding three patterns of preschool behavior. Genetic Psychology Monographs. 75: 43-88.

Dornbusch SM, Ritter PL, Leiderman PH, Roberts DF, Fraleigh MJ. 1987. The relation of parenting styles to adolescent school performance. Child Development. 58 (5), 1244-1257.

Erden M, Uredi I. 2008. The effect of perceived parenting styles on self-regulated learning strategies and motivational beliefs. International Journal about Parents in Education. 2(1), 25-34.

Farooq MS, Chaudhry AH, Shafiq M, Berhanu G. 2011. Factors affecting students' quality of academic performance: A case of secondary school level. Jurnal of Quality and Technology Management. 3(2), 01-14.

Grolnick WS, Ryan RM. 1989. Parent styles associated with children's self regulation and competence in school. Journal of Education Psychology. 81(2), 143154.American Psychological Association, Inc.

Hastuti D. 2009. Pengasuhan: Teori dan Prinsip serta Aplikasinya di Indonesia. Bogor (ID): Departemen Ilmu Keluarga dan Konsumen. Fakultas Ekologi Manusia. IPB.

Ho ESC. 2005. Self regulated learning and academic achievement of Hong Kong secondary school students. Education Jurnal. 32 (2).

Long JF, Monoi S, Harper B, Knoblauch D, Murphy PK. 2007. Academic motivation and achievement among urban adolescents. Urban Education. 42(3), 196-222.

Maccoby EE, Martin JA. 1983. Socialization in the contex of the family: Parent-child interaction.Handbook of Child Psychology $4^{\text {th }}$ Edition. Socialization, personality, and social development, 4, 1-101. New York: Wiley. 
Pintrich PR, De Groot EV. 1990. Motivational and self-regulated learning components of classroom academic performance. Journal of Educational Psychology. 2(1), 33-40.

Purdie N, Carrol A, Roche L. 2004. Parenting and adolescent self-regulation. J Adolesc. 27(6), 663-676.

Rahmaisya R. 2011. Pengaruh Gaya pengasuhan Orangtua dan Konsep Diri terhadap Motivasi Berprestasi Atlet Muda di SMA Negeri Ragunan Jakarta [skripsi]. Bogor: Institut Pertanian Bogor.

Salmeron-Perez H, Gutierrez-Braojos C, Fernandez-Cano A, Salmeron-Vilchea P. 2010. Self regulated learning, self efficacy beliefs, and performance during the late childhood. RELIEVE. 6, 1-18.

Santrock JW. 2002. Life Span Development: Perkembangan Masa Hidup. Damanik J, Chusairi A, penerjemah; Kristiaji WC, Sumiharti Y, editor. Jakarta (ID): Erlangga.

Schunk DH, Meece JL. 2005. Self-efficacy development in adolescences. In SelfEfficacy Beliefs of Adolescents (71-96). Information Age Publishing.

Stephens MA. 2009. Gender differences in parenting styles and effects on the parent child relationship [thesis]. Texas State University. USA: Texas, San Marcos.

Tam CL, Chong A, Kadirvelu A, Khoo YT. 2012. Parenting styles and self-efficacy of adolescents: Malaysian scenario. Global Journal of Human Social Science. 12(4). USA: Global Journals Inc.

Zimmerman BJ. 1989. A social cognitive view of self-regulated academic learning. Journal of Educational Psychology. 81, 329-339.

- 1990. Self-regulated learning and academic achievement: An overview. Educational Psychologist. 25(1), 3-17.

, Martinez-Pons M. 1990. Studentdifferences in self-regulated learning: Relating grade, sex, and giftedness to self efficacy and strategy use. Journal of Education Psychology. 82(1), 51-5. 
